\title{
Molecular diagnosis of Hepatozoon canis in symptomatic dogs in the city of Goiania, Goiás, Brazil
}

[Diagnóstico molecular de Hepatozoon canis em cães sintomáticos do município de Goiânia, Goiás, Brasil]

\author{
S.C. Duarte ${ }^{1}$, J.A. Parente ${ }^{1}$, O.J. Silveira Neto ${ }^{2 *}$, V.S. Jayme ${ }^{1}$, T.S.A. Bastos ${ }^{3}$, G.F.C. Linhares ${ }^{4}$ \\ ${ }^{1}$ Universidade Federal de Goiás - Goiânia, GO \\ ${ }^{2}$ Universidade Estadual de Goiás - São Luis de Montes Belos, GO \\ ${ }^{3}$ Aluno de pós-graduação - Escola de Veterinária e Zootecnia - Goiânia, GO \\ ${ }^{4}$ Escola de Veterinária e Zootecnia - Goiânia, GO
}

\begin{abstract}
More than 300 species have been described in the genus Hepatozoon, occurring in different vertebrates. Among these, only Hepatozoon canis and Hepatozoon americanum are seen in dogs. Different methods may be used for laboratory diagnosis. The most common of these is direct parasitological examination of parasite stages in blood smears. The aim of this investigation was to conduct a phylogenetic study on Hepatozoon isolates from symptomatic dogs in the city of Goiânia, Goiás, Brazil. Blood samples were obtained from 40 symptomatic dogs that had been referred to the Veterinary Hospital of the Federal University of Goiás. Among these, only two samples were positive for Hepatozoon spp. using the direct parasitological method. These samples were then subjected to a DNA extraction process and amplification of a fragment of the 18S rRNA by means of PCR. Subsequently, the PCR products from each sample were purified and sequenced. The sequences obtained were then analyzed using the BLASTn algorithm, which identified both sequences of this study as Hepatozoon canis. By applying the Mega4 software, it was confirmed that these isolates of $H$. canis from dogs in Goiânia are similar to other reference isolates of the same species from other regions of Brazil and worldwide.
\end{abstract}

Keywords: Canis familiaris, hepatozoonosis, molecular epidemiology, phylogeny

\section{RESUMO}

São descritas mais de 300 espécies do gênero Hepatozoon que acometem diferentes vertebrados. Entre estas, apenas Hepatozoon canis e Hepatozoon americanum são descritas em cães. Diferentes métodos podem ser utilizados para o diagnóstico laboratorial. O mais empregado é o exame parasitológico direto do parasito em esfregaços sanguíneos. O objetivo deste trabalho foi realizar um estudo filogenético em Hepatozoon isolados de cães sintomáticos de Goiânia, Goiás. As amostras de sangue foram obtidas de 40 cães sintomáticos encaminhados ao Hospital Veterinário da Universidade Federal de Goiás. Entre essas, duas únicas amostras foram positivas para Hepatozoon spp. pelo método parasitológico direto. Estas amostras foram, então, submetidas ao processo de extração de DNA e de amplificação de um fragmento de $18 S$ rRNA por PCR. Ambas as amostras foram positivas na PCR. Posteriormente, os produtos de PCR de cada amostra foram purificados e sequenciados. As sequências obtidas foram analisadas pelo algoritmo BLASTn, sendo identificadas como Hepatozoon canis. Por meio do software Mega4 foi confirmado que estes isolados de $\mathrm{H}$. canis de cães de Goiânia são semelhantes a outros isolados de referência da mesma espécie de outras regiões do Brasil e do mundo.

Palavras-chave: Canis familiaris, hepatozoonose, epidemiologia molecular, filogenia

Recebido em 1 de novembro de 2015

Aceito em 4 de abril de 2016

* Autor para correspondência (corresponding author)

E-mail: osvaldonetovet@hotmail.com 


\section{INTRODUCTION}

The first species relating to the genus Hepatozoon was observed by Bentley in India in 1905, during an examination on polymorphonuclear cells of dogs. In the same year, also in India, James observed the protozoa in the cytoplasm of peripheral blood leukocytes of six dogs and classified them as Leucocytozoon canis. In 1910, in reviewing the comments of Bentley and James, Wenyon suggested that the generic name Leucocytozoon should be replaced by Hepatozoon (Greene, 2006; Rahmani Amoli et al., 2012).

Today, more than 300 species of the genus Hepatozoon have been identified in different vertebrates, including amphibians, reptiles, marsupials, birds and mammals, and these can be transmitted by different vectors, including ticks, lice, mosquitoes, sand flies, tsetse flies, flea mites and triatomines (Metzer et al., 2008). Two species are recognized as causing disease in dogs: Hepatozoon canis and Hepatozoon americanum. H. canis is a parasite that affects dogs in various regions with the highest prevalence in Africa, Asia and southern Europe, while $H$. americanum infects dogs in the southern United States (Baneth \& Shkap, 2003).

In Brazil, hepatozoonosis due to $H$. canis was first reported by Massard (1979) in dogs in Rio de Janeiro. Subsequently, similar accounts were registered in the state of São Paulo (O'Dwyer et al., 1997), state of Minas Gerais (Mundin et al., 1992) and the Federal District (Paludo et al., 2005).

The tick Rhipicephalus sanguineus has been recognized as a vector species of $H$. canis in various parts of the world. However, in Brazil, only Amblyomma ovale has been confirmed as a vector species for this in experimental studies (Forlano et al. 2005; Rubini et al. 2009). The infection in dogs due to $H$. canis can range from subclinical, with low-level parasitemia, to serious disease that threatens the animal's life, especially in young or immunosuppressed individuals (Hervas et al., 1995).

The method routinely used to diagnose $H$. canis is based on microscopic identification of intraleukocyte gametocytes in peripheral blood smears stained with Giemsa (Ibrahim et al.,
1989; Baneth \& Weigler, 1997). The gametocytes quickly leave the leukocytes after blood sampling, mainly through contact between the blood and the EDTA anticoagulant, which may make it difficult to search for gametocytes in blood smears (Vincent-Johnson et al., 1997).

Development of new diagnostic techniques such as the polymerase chain reaction (PCR) has provided investigative advances, regarding detection and identification of Hepatozoon species in dogs, and has also assisted in making taxonomic classifications of these and other infectious agents. PCR can also help in detecting new strains or species variants, and allows early detection of infection (Perkins \& Keller, 2001).

Early research involving Hepatozoon species and molecular techniques began in the 1990's. Hepatozoon species infecting snakes were genetically characterized. Phylogenetic studies involving molecular characterization of Hepatozoon species affecting dogs only started in 2000. The studies by Mathew et al. (2000) and Inokuma et al. (2002) are prominent among these.

In Brazil, different studies involving molecular analyses have confirmed the presence of $H$. canis in naturally infected dogs (Forlano et al., 2005; Rubini et al., 2008; Spolidorio et al., 2009), cats (Perez et al., 2004) and wild felines (Metzger et al., 2008).

The aims of the present investigation were to conduct a study on the frequency of occurrences of Hepatozoon sp. among dogs with symptoms suggestive of hemoparasitosis that were treated at the Veterinary Hospital of the Federal University of Goiás (UFG), in the city of Goiânia, state of Goiás, Brazil, and to carry out molecular characterization and phylogenetic analysis on the Hepatozoon samples thus obtained.

\section{MATERIALS AND METHODS}

Forty samples from dogs with clinical signs suggestive of hemoparasitosis were selected according to convenience. These animals had been referred for consultation at the Veterinary Hospital of the Veterinary and Zootechnics School, UFG. They had histories of tick 
infestation, fever, pale mucosa, anorexia and prostration.

Blood samples with anticoagulant (Universal anticoagulant, Doles ${ }^{\circledR}$ ) were taken from these animals to perform direct parasitological examinations as a screening method for identifying animals that were carriers of gametocytes of Hepatozoon sp. Morphological identification was performed by means of microscopic examination of blood smears stained with Giemsa. All samples, regardless of whether the parasite was present, were used for the molecular characterization. The present work was approved by the UFG Ethics Committee (CEUA 02/11).

From the animals sampled, tick specimens were also collected. These were kept in $70 \%$ ethanol for subsequent species identification, using the Bechara identification key (2006). All 40 samples of this study were subjected to a DNA extraction process using a commercial kit (GFX-Genomic Blood DNA Purification Kit ${ }$, Amersham Biosciences). The extraction procedures were performed in accordance with the manufacturer's instructions, using the protocol established for extraction from a blood volume of $100 \mu \mathrm{L}$. The eluates were stored at $20^{\circ} \mathrm{C}$.

The samples of total DNA extracted from each blood aliquot $(n=40)$ were subjected to the process of enzyme amplification in order to obtain fragments of the target 18S rRNA gene. For this purpose, we used the following oligonucleotides: sense (5'-GGC CAC TAC ATC GGA TAA AG-3 ') and antisense (5'-CTA AGA ATT TCA CCT CTG ACA G-3').

The PCR assays were performed using a volume of $50 \mu \mathrm{L}$, with the following reagent concentrations: $1 \mathrm{X}$ PCR buffer (10X PCR buffer, Invitrogen $\left.{ }^{\circledR}\right), \quad 2.0 \mathrm{mM}$ magnesium chloride $\left(\mathrm{MgCl}_{2}\right)$ (Invitrogen $\left.{ }^{\circledR}\right), 0.2 \mathrm{mM}$ dNTP (Amersham Biosciences ${ }^{\circledR}$ ), $10 \mathrm{pM}$ of sense primer, $10 \mathrm{pM}$ of antisense primer, $1.25 \mathrm{U}$ of Taq DNA polymerase (Taq DNA polymerase $5 \mathrm{U} / \mu \mathrm{L}$, Invitrogen $\left.{ }^{\circledR}\right)$ and $5 \mu \mathrm{l}$ of genomic DNA extracted from the sample as described above. The amplification process was carried out in thermocycler (Mastercycler Personal, Eppendorf $\left.{ }^{\circledR}\right)$, which was set to an initial cycle of $94^{\circ} \mathrm{C}$ for $2 \mathrm{~min}$., followed by 35 repeated cycles of $94^{\circ} \mathrm{C}$ for $30 \mathrm{sec} ., 56^{\circ} \mathrm{C}$ for $30 \mathrm{sec}$. and $72^{\circ} \mathrm{C}$ for $1 \mathrm{~min}$. The program ended with $2 \mathrm{~min}$. at $72^{\circ} \mathrm{C}$ to maximize the extension process.

As a positive control for the PCR reactions, we used a sample of genomic DNA reference for Hepatozoon spp. that was obtained in the Diagnostic Laboratory for Parasitic Diseases, Veterinary School, UFG.

The amplification products were displayed on $1.5 \%$ agarose gel (Agarose NA, Amersham Biosciences $\left.{ }^{\circledR}\right)$ in $1 x$ TBE buffer containing $10 \mu \mathrm{L}$ of the sample, which was subjected to electrophoresis at 90 volts for $60 \mathrm{~min}$. A molecular weight marker of $100 \mathrm{bp}$ was used (DNA Ladder 100bp; Invitrogen ${ }^{\circledR}$ ).

After cycling, the gels were stained by soaking them in a solution of ethidium bromide $(0.4 \mu \mathrm{g} / \mathrm{ml})$ for $10 \mathrm{~min}$. The gels were viewed in a UV transilluminator (Electronic UV Transilluminator, Ultra-Lum ${ }^{\circledR}$ ) and photographic documentation was made using appropriate equipment (Vilber Lourmat ${ }^{\circledR}$ ).

Only the PCR products that tested positive were purified. Positive samples were cut and removed from the gel after electrophoresis, under UV light, and were purified to obtain clean fragments, using a commercial kit (QIAquick Gel Extraction Kit Protocol, Qiagen $®)$. After identification, the samples were refrigerated for sequencing to be performed.

Sequencing was done on an automated sequencer (MegaBACE1000; GE Healthcare $\left.{ }^{\circledR}\right)$, using the dideoxy method (ddNTP) and the DYEnamic ${ }^{\mathrm{TM}}$ ET dye terminator kit (MegaBACE ${ }^{\mathrm{TM}}$; GE Healthcare $\left.{ }^{\circledR}\right)$. The sequences obtained were analyzed using the Phred software, to ensure that the product quality index was greater than or equal to 20 .

The sequences obtained from the PCR products were analyzed for similarity by means of the BLASTn algorithm (http://www.ncbi.nlm.nih.gov), and then were compared with the database sequences from GenBank. The sequences of samples were analyzed for percentage identities, using the method of multiple sequence alignments in ClustalW (Thompson et al. 1999) and using the MEGA4 software (Molecular Evolutionary Genetics Analysis - Software 
Version 4, Tamura et al. 2007). The same identity analysis was performed by comparing the samples from this study with the GenBank reference sequences of $H$. canis from different geographical regions and with the sequences of H. americanum (AF176836 and EU146062) and H. catesbianae (AF176837).

For the phylogenetic analysis, a dendrogram including partial sequences of the $18 \mathrm{~S}$ rRNA gene was constructed. These sequences were used as references for different regional Hepatozoon canis samples, comparing them with the samples obtained in this study. The reference strains included in this analysis and their GenBank accession numbers were as follows: $H$. canis: Brazil (FJ743476.1), Brazil (DQ198378), Brazil (EF650846.1), Brazil (EU571737.1) Brazil (AY461376) and Brazil (DQ071888); H. canis Croatia (FJ497022.1), H. canis Spain (DQ439542.1), H. canis France (EU622910.1), $H$. canis Israel (AF176835), H. canis Spain (AY150067). The 18S rRNA sequence of $P$. vivax was included in the tree as an organism that is phylogenetically distant, for rooting the tree.

The alignments were performed by means of the ClustalW method, in order to construct a neighbor-joining phylogenetic tree with 1000 bootstrap replicates and evolutionary distance parameters adjusted using the Kimura 2parameter substitution method.

\section{RESULTS}

Over the study period, blood samples were collected from 40 dogs with clinical signs suggestive of hemoparasitosis. Among these, only two were positive for Hepatozoon $s p$. in the direct parasitological examination, i.e. a frequency of $5 \%$.

Sample number 1 was obtained from an eightyear-old female Dachshund. The parasitological examination showed extracellular gametocytes (Fig. 1a). Sample number 2 was obtained from a seven-year-old male dog of mixed breed (Fig. $1 b)$.

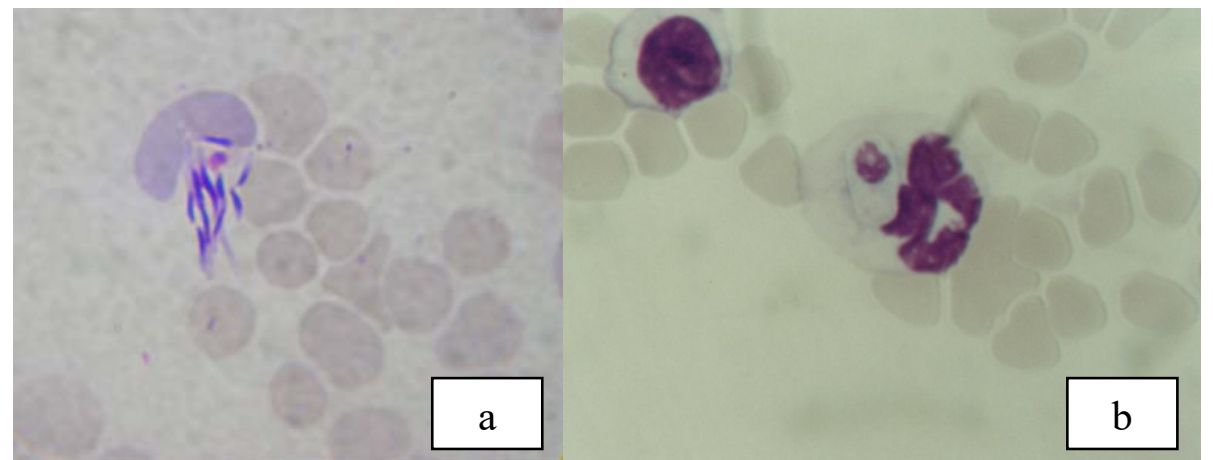

Figure 1. a: Hepatozoon sp. gametocyte observed in an eight-year-old female Dachshund, in the city of Goiânia, Goiás (1000x) b: Hepatozoon sp. gametocyte inside the neutrophil of a seven-year-old male dog, in the city of Goiânia, Goiás (1000x).

The parasitological examination on this sample showed intra-leukocyte gametocytes typical of Hepatozoon sp. These two animals showed nonspecific signs at the clinical examination, such as fever, pale mucosa, anorexia and prostration.

Identification of tick specimens was only performed in relation to the dogs in which Hepatozoon sp was parasitologically detected. Between the two dogs with Hepatozoon sp in the present study, only number 1 had ticks during the clinical examination. The analysis was performed on nymphs and on adult male and adult female ticks. After evaluation using a tick identification key, the instars were classified as Rhipicephalus sanguineus.

The 40 samples were subjected to PCR reactions. The two samples with a positive result from PCR were the same samples that were positive in the parasitological examination and generated fragments of $500 \mathrm{bp}$ from the $18 \mathrm{~S}$ rRNA gene of Hepatozoon spp (Fig. 2). 


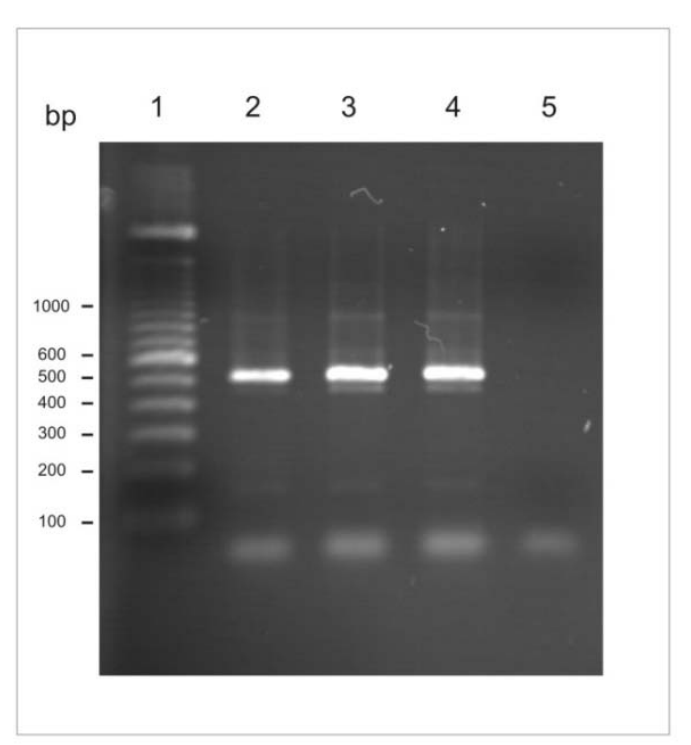

Figure 2. Electrophoresis of PCR products showing a 500bp amplified Hepatozoon sp. DNA sample obtained from symptomatic dogs. Line 1: 100bp marker; Line 2: positive control; lines 3 and 4: sample nos. 1 and 2 of $H$. Canis; and line 5: negative control.

After the purified PCR products had been sequenced, both samples were subjected to evaluation by means of BLASTn. The analysis of similarities confirmed that the samples of this study corresponded to the species $H$. canis. The samples were deposited in GenBank as new sequences for the 18S rRNA gene of Hepatozoon canis, with the identification numbers GU386283 and GU386284.

The sequences were then adjusted to the same length of $191 \mathrm{bp}$ before multiple alignment was performed for the similarity and nucleotide polymorphism analyses. In this evaluation, the two sequences designated $H$. canis GO 01 and $H$. canis GO 02 showed 100\% similarity to each other and to samples obtained from urban dogs elsewhere in Brazil and in Croatia and Spain.

Among the Brazilian references, only the isolate EF650846 showed nucleotide variation, with $98.95 \%$ similarity. This difference was shown by two substitutions at position 89 and 176 of the alignment. Also with $98.95 \%$ similarity and two substitutions, the isolate from Israel showed variations at positions 21 and 176 of the alignment. The Brazilian isolate AY461376 and the one from Spain showed $99.48 \%$ similarity, in comparison with the others.

The greatest variation was from the French isolate, with three substitutions at positions 21 , 30 , and 176 , but high similarity, of 98.43 , was still maintained. The comparative analysis on the samples in this study revealed $96.8 \%$ and $94.20 \%$ similarity to samples of $H$. americanum and $H$. catesbianae respectively (Tab. 1$)$.

Table 1. Comparison of 18S rRNA sequences of the Goiânia Hepatozoon canis gene with other sequences from different geographical regions, based on the number of polymorphic positions of genotypes of Hepatozoon canis 01

\begin{tabular}{|c|c|c|c|c|c|c|c|}
\hline \multirow[t]{2}{*}{ Genotypes/samples } & \multirow{2}{*}{$\begin{array}{c}\text { GenBank } \\
\text { access } \\
\text { numbers }\end{array}$} & \multirow[t]{2}{*}{ Similarity $^{\mathrm{a}}(\%)$} & \multicolumn{5}{|c|}{ Position of nucleotide polymorphism } \\
\hline & & & 21 & 30 & 89 & 162 & 176 \\
\hline H. canis GO 01 & GU386283 & - & G & $\mathrm{C}$ & $\mathrm{T}$ & G & $\mathrm{G}$ \\
\hline H. canis GO 02 & GU386284 & 100.00 & - & • & $\bullet$ & $\bullet$ & $\bullet$ \\
\hline Brazil & FJ743476 & 100.00 & $\bullet$ & • & • & $\bullet$ & $\bullet$ \\
\hline Brazil & DQ198378 & 100.00 & • & $\bullet$ & • & $\bullet$ & - \\
\hline Brazil & EF650846 & 98.95 & - & • & A & • & A \\
\hline Brazil & EU571737 & 100.00 & - & • & $\bullet$ & • & $\bullet$ \\
\hline Brazil & DQ071888 & 100.00 & $\bullet$ & • & $\bullet$ & • & • \\
\hline Brazil & AY461376 & 99.48 & $\bullet$ & $\bullet$ & • & A & • \\
\hline Croatia & FJ497022 & 100.00 & • & • & - & - & • \\
\hline Spain & DQ439542 & 99.48 & - & • & • & A & - \\
\hline Spain & AY150067 & 100.00 & • & $\bullet$ & $\bullet$ & - & - \\
\hline Israel & AF176835 & 98.95 & A & $\bullet$ & • & • & A \\
\hline France & EU622910 & 98.43 & A & $\mathrm{T}$ & - & • & A \\
\hline
\end{tabular}




\section{Duarte et al.}

The phylogenetic tree generated by comparison between the partial sequences of the $18 \mathrm{~S}$ rRNA gene of regional samples $H$. canis GO 01 and $\mathrm{H}$. canis GO 02 and the corresponding reference sequences for other species of the genus Hepatozoon included in this analysis revealed that: (1) the species Hepatozoon canis and $H$. americanum were separated into distinct "clades". The $H$. canis sequences from Brazil were grouped in the same "clade" (bootstrap = $62 \%$ ), thus showing the high similarity between them. The "clade" formed by strains of $H$. canis was supported by a bootstrap value of $92 \%$. (2) The Goiânia sequences of this study were grouped into the same "clade" composed by reference strains of $H$. canis in other geographical regions (Fig. 3).

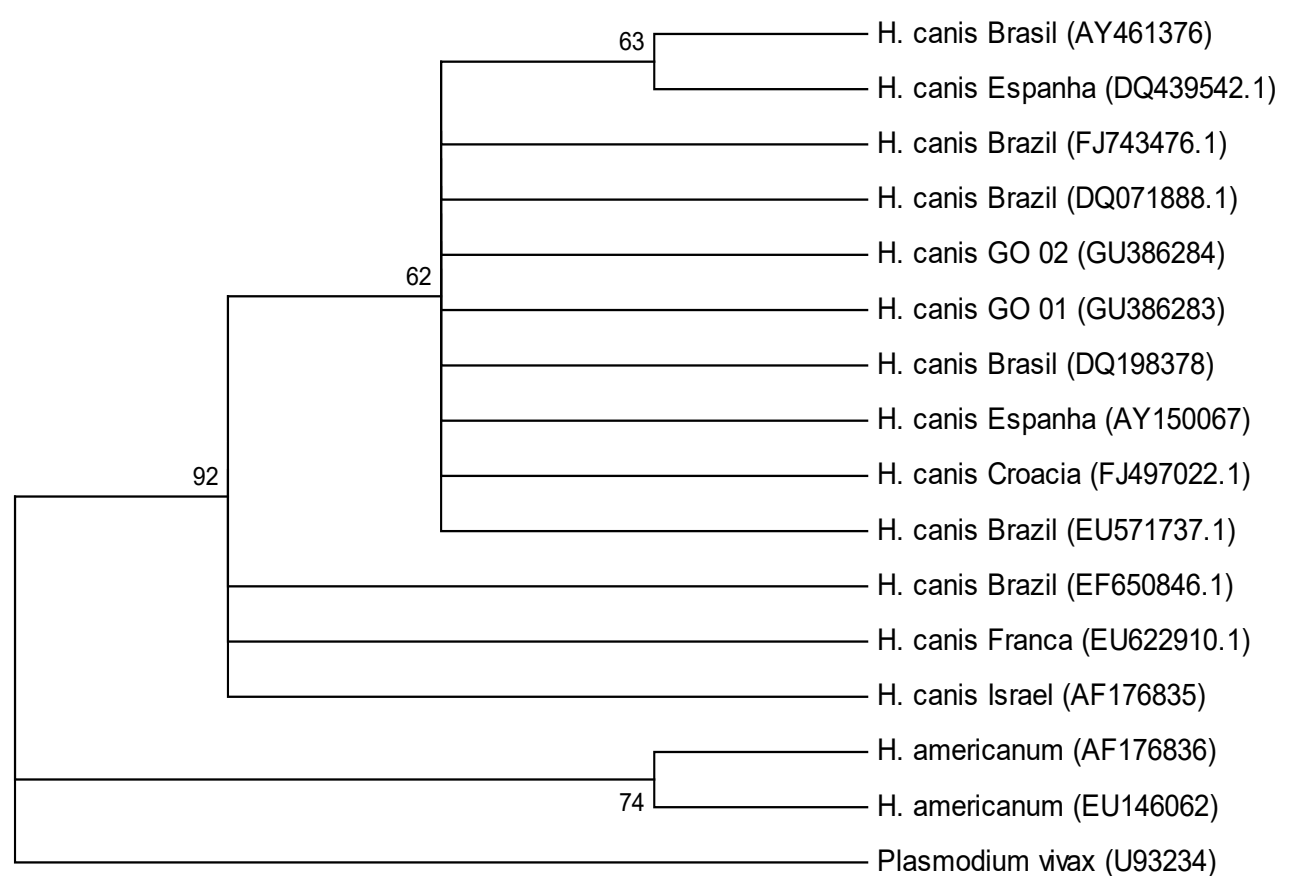

Figure 3. Phylogenetic tree based on fragments of the partial 18S rRNA Hepatozoon sp. gene of regional samples. The tree was constructed using the neighbor-joining method with bootstrap values calculated from 1000 trees. Accession numbers in brackets.

\section{DISCUSSION}

The low percentage of positive animals $(5 \%)$ in the direct parasitological examination for $H$. canis, among animals with clinical signs suggestive of the disease, can be explained by the fact that dogs with hepatozoonosis do not show signs that are recognized as pathognomonic. These suggestive signs may also be caused by other hemoparasitosis or by different diseases. According to Baneth \& Shkap (2003), when animals have fever, anorexia, weight loss, pale mucous membranes, eye discharge and hind limb weakness, the disease might be suspected. The dogs evaluated in this study had nonspecific clinical signs similar to those reported by O'Dwyer and Massard (2002).
These signs are consistent with those cited by Greene (2006), who reported on cases ranging from accidental hematological findings in healthy dogs to debilitated animals. $H$. canis in symptomatic animals was also cited in the state of São Paulo (Gondim et al., 1998) and in Brasilia (Paludo et al., 2003), thus corroborating the results obtained in this study.

The vector for hepatozoonosis is recognized worldwide as the tick Rhipicephalus sanguineus. So far, this has not been confirmed in experiments conducted in Brazil, although these ticks have been identified in dogs with the agent in different regions of the country. At the moment, only the Amblyomma ovale has been proven to be a vector. In the present study, the 
species $R$. sanguineus was only identified in one of the dogs evaluated, and no other tick species were identified. This is not a conclusive finding with regard to participation of the species $R$. sanguineus in the transmission of hepatozoonosis, even though this possibility was previously pointed out by Forlano et al. (2005), Baneth et al. (2007), and Rubini et al. (2009).

Including the signs mentioned above, two dogs in this study also presented gametocytes of Hepatozoon sp. in the direct parasitological examination. Presence of free gametocytes, as observed in this study, had already been mentioned by Lainson et al. (2003), and Lima and Silva (2004) in their studies on samples of $H$. caimani from alligators. Vincent-Johnson et al. (1997) stated that the gametocytes quickly leave the leukocytes of the blood, especially consequent to contact between blood and anticoagulant. This may also explain the finding of an extracellular parasite in one of the samples evaluated.

The parasitological examination does not provide any reliable differentiation between Hepatozoon species. This has motivated use of molecular biology techniques in studies on the etiology and epidemiology of canine hepatozoonosis. Several authors like Inokuma et al. (2002), Forlano et al. (2005), Rubini et al. (2008), and Spolidorio et al. (2009) have used PCR to identify these agents. As already mentioned, PCR reactions performed on two samples obtained in this study confirmed the presence of Hepatozoon sp. in these samples.

The similarity analysis between the two regional sequences and the GenBank sequences obtained from the database revealed similarity to the $18 \mathrm{~S}$ rRNA gene of $H$. canis. So far, all studies conducted in Brazil that were based on molecular biology methods have had similar results, including the results from the present study. This can be seen in relation to the studies by Rubini et al. (2008) in Sao Paulo, Paludo et al. (2005) in Brasilia, Lasta et al. (2009) in Rio Grande do Sul, and Spolidorio et al. (2009) in Espírito Santo, using samples obtained from dogs. Other studies have also been developed using samples from cats and the only species identified was still H. canis (Metzer et al., 2008).

Similarity analysis on the samples of this study in comparison with other Brazilian isolates showed $100 \%$ identicalness with most of the other studies. The genetic variability among Brazilian isolates of $H$. canis was minimal, as reported by Lasta et al. (2009).

In the present study, a comparison was also made between regional samples of $H$. canis isolates and a reference isolate of $H$. americanum. The similarity observed was $96.8 \%$. In a similar study also conducted with two samples from dogs, Inokuma et al. (2002) found 94\% similarity, comparing isolates from Japan with isolates from Israel. The result confirms that there is a genetic difference between the species $H$. canis and $H$. americanum, albeit small, as previously reported by different studies like those developed by Vincent-Johnson et al. (1997) and Mathew et al. (2000).

Considering the large territorial extent of Brazil and the little research in this field, it is clear that there is a need to broaden the investigations and stimulate further studies, focusing primarily on epidemiology, diagnostic methods, molecular characterization and phylogeny in different biological samples, as emphasized by Metzer et al . (2008).

This study is the first molecular characterization of Hepatozoon developed in the state of Goiás. It allowed identification of Hepatozoon canis that was present in dogs treated at the Veterinary Hospital of UFG. Further studies are needed, considering the importance of obtaining more data from different regions of Brazil. Likewise, studies involving experimental transmission and molecular biology are needed in order to obtain information about the species and the possible existence of genogroups in the genus Hepatozoon occurring in this country.

\section{CONCLUSION}

This molecular characterization study based on phylogenetic methods confirmed occurrences of Hepatozoon canis in dogs with compatible clinical signs of hepatozoonosis in Goiânia, Goiás. The isolates of $H$. canis from the city of Goiânia were phylogenetically identical to isolates from elsewhere in Brazil and were also similar to reference isolates from other geographical regions. 


\section{REFERENCES}

BANETH, G.; SAMISH, M.; SHKAP, V. Life cycle of Hepatozoon canis in the tick Rhipicephalus sanguineus and domestic dog (Canis familiaris). J. Parasitol., v.93, p.183-299, 2007.

BANETH, G.; SHKAP, V. Monozoic cysts of Hepatozoon canis. J. Parasitol., v.89, p.379-381, 2003.

BANETH, G.; WEIGLER, B. Retrospective case-control study of hepatozoonosis in dogs in Israel. J. Vet. Intern. Med.,v.11, p.365-370, 1997.

BECHARA, G.H. Imunopatologia da interação carrapato-hospedeiro. In: BARROS-BATTESTI, D.M.; ARZUA, M.; BECHARA, G.H. Carrapatos de importância médico-veterinária da região neotropical par: um guia ilustrado a identificação das espécies. São Paulo: Vox/ICTTD-3/Butantan, 2006.

FORLANO, M.; SCOFIELD, A.; ELISEI, C. et al. Diagnosis of Hepatozoon spp. in Amblyomma ovale and its experimental transmission in domestic dogs in Brazil. Vet. Parasitol., v.25, p.1-7, 2005.

GONDIM, L.F.P.; KONAYAGAWA, A.; ALENCAR, N.X. et al. Canine hepatozoonosis in Brazil: description of eight naturally occurring cases. Vet. Parasitol. v.74, p.319-323, 1998.

GREENE, C.E. Infectious diseases of the dog and cat. Canada: Saunders, 2006. 1387p.

HERVAS, J.; CARRASCO, L.; GOMEZVILLAMANDOS, J.C. Acute fatal hepatozoonosis in a puppy: histopathological and ultrastructural study. Vet. Res., v.137, p.518-519, 1995.

IBRAHIM, N.D.G.; RAHAMATHULLA, P.M.; NJOKU, C.O. Neutrophil myeloperoxidade deficiency associated with canine hepatozoonosis. Int. J. Parasitol., v.19, p.915918, 1989.

INOKUMA, H.; OKUDA, M.; OHNO, K.; SHIMODA, K. et al. Analysis of the 18S rRNA gene sequence of a Hepatozoon detected in two Japanese dogs. Vet. Parasitol., v.106, p.265-271, 2002.
LAINSON, R.; PAPERNA, I.; NAIFF, R.D.; Development of Hepatozoon caimani (Carini, 1909) Pessoa, de Biasi \& de Souza, 1972 in the caiman Caiman c. crocodilus, the frog Rana catesbeiana and the mosquito Culex fatigans. Mem. Inst. Oswaldo Cruz, v.98, p.103-113, 2003.

LASTA, C.S.; SANTOS, A.P.S.; MELLO, F.P.S. et al. Infecção por Hepatozoon canis em canino doméstico na região Sul do Brasil confirmada por técnicas moleculares. Ciênc. Rural, v.39, p.135-215, 2009.

LIMA, E.S.S.; SILVA, R.A.M.S. Aspectos morfológicos do parasita Hepatozoon caimani em jacaré (Caiman crocodilua yacare) no Pantanal do Sul. Corumbá: Embrapa, 2004. 4p. (Comunicado Técnico, n.41).

MASSARD, C.A. Hepatozoon canis (JAMES, 1905) (Adeleida: Hepatozoidae) cães do Brasil, com uma revisão do gênero em membros da ordem carnívora. 1979. 121f. Dissertação (Mestrado em Parasitologia Veterinária) Faculdade de Medicina Veterinária, Instituto de Biologia, Universidade Federal Rural do Rio de Janeiro, Itaguaí, RJ.

MATHEW, J.S.; VAN DEN BUSSCHE, R.A.; EWING, S.A. et al. Phylogenetic relationships of Hepatozoon (Apicomplexa: Adeleorina) based on molecular, morphologic, and life-cycle characters. J. Parasitol., v.86, p.366-372, 2000.

METZER, B.; PADUAN, K.S.; RUBINI, A.S. et al. The first report of Hepatozoon sp. (Apicomplexa: Hepatozoidae) in neotropical felids from Brazil. Vet. Parasitol. v.152, p.28-33, 2008.

MUNDIM, A.V.; JACOMINI, J.O.; MUNDIM, M.J.S. Hepatozoon canis (James, 1905) em cães de Uberlândia, Minas Gerais: relato de dois casos. Braz. J. Vet. Res. Anim. Sci., v.29, p.259261, 1992.

O'DWYER, L.H.; GUIMARÃES, L.; MASSARD, C.L. Ocorrência de infecção múltipla por Babesia canis, Hepatozoon canis e Haemobartonella canis em um cão esplenectomizado. Rev. Bras. Ciênc. Vet., v.4, p.83-84, 1997. 
O'DWYER, L.H.; MASSARD, C.L. Hepatozoonose em pequenos animais domésticos e como zoonose. In: NADIA, R.P. (Ed.). Hemoparasitoses em pequenos animais domésticos e como zoonoses. Rio de Janeiro: L.F. Livros de Veterinária, 2002. [135p.]

PALUDO, G.R.; DELL'PORTO, A.; CASTRO, A.R.C. et al. Hepatozoon spp.: report of some cases in dogs in Brasilia, Brazil. Vet. Parasitol., v.118, p.243-248, 2003.

PALUDO, G.R.; FRIEDDMANN, H.; DELL'PORTO, A. et al. Hepatozoon spp.: pathological and partial 18S rRNA sequence analysis from three Brazilian dogs. Vet. Parasitol., v.97, p.167-170, 2005.

PEREZ, R.R.; RUBINI, A.S.; O’DWYER, L.H. The first report of Hepatozoon spp. (Apicomplexa, Hepatozoidae) in domestic cats from São Paulo state, Brazil. Parasitol. Res., v.94, p.83-85, 2004.

PERKINS, S.L.; KELLER, A.K. Phylogeny of nuclear small subunit rRNA genes of hemogregarines amplified with specific primers. J. Parasitol., v.87, p.870-876, 2001.

RAHMANI AMOLI, A.A.; KHOSHNEGAH, J.; RAZMI, G.R. A Preliminary parasitological survey of Hepatozoon spp. infection in dogs in Mashhad, Iran. Iran J. Parasitol., v.7, p.99-103, 2012.
RUBINI, A.S.; PADUAN, K.S.; LOPES, V.V.; O'DWYER, L.H. Molecular and parasitologycal survey of Hepatozoon canis in dogs from rural area of Sao Paulo state, Brazil. Parasitol. Res., v.102, p.895-899, 2008.

RUBINI, A.S.; PADUAN, K.S.; MARTINS, T.F. et al. Acquisition and transmission of Hepatozoon canis (Apicomplexa: Hepatozoidae) by the tick Amblyomma ovale (Acari: Ixodidae). Vet. Parasitol., v.164, p.324-327, 2009.

SPOLIDORIO, M.G.; LABRUNA, M.B.; ZAGO, A.M. et al. Hepatozoon canis infecting dogs in the state of Espírito Santo, southeastern Brazil. Vet. Parasitol., v.163, p.357-361, 2009.

TAMURA, K.; DUDLEY, J.; NEI, M. MEGA4: molecular evolutionary genetics analysis (MEGA) software version 4.0. Mol. Biol. Evol., v.24, p.1596-1599, 2007.

THOMPSON, J.D. A comprehensive comparison of multiple sequence alignment programs. Nuc. Acids. Res., v.27, p.2682-2690, 1999.

VICENT-JOHNSON, N.A.; LINDSAY, D.L.; LENZ, S.D. et al. New Hepatozoon species from dogs: description of the causative agent of canine hepatozoonosis in north America. $J$. Parasitol.,v.83, p.1165-1172, 1997. 